\title{
Apparel shopping orientation: Two decades of research
}

\author{
Elizabeth M Visser and Ronel du Preez
}

\begin{abstract}
OPSOMMING
Aankooporiëntasie word gedefinieer as ' $n$ verbruiker se aankoopstyl wat spesifieke nadruk plaas op koopspesifieke lewenstyle insluitend aankoopaktiwiteite, belangstellings en opinies. Dit reflekteer ' $n$ beskouing van aankope as ' $n$ komplekse persoonlike, sosiale, ekonomiese en ontspanningsfenomeen. Dit blyk uit die literatuur dat aankooporiëntasie ' $n$ persoonlike dimensie en ' $n$ markgedragdimensie het wat gestalte vind in ' $n$ algemene benadering tot die verkryging van goedere en dienste wat voorkeure t.o.v. inligtingsbronne, die winkel (winkelvoorkeurgedrag) en winkeleienskappe (insluitend winkelbeeld) omvat.
\end{abstract}

Die doel van die studie is om navorsing oor kooporiëntasie van klereverbruikers op te teken en te analiseer. Die keuse van artikels is gebaseer op die volgende kriteria: a) empiriese navorsing oor kooporiëntasie in die algemeen en spesifiek ten opsigte van klere, b) publikasie in ' $n$ professionele tydskrif gedurende die periode 1980 tot 1999. Die inligting wat opgeteken en ontleed is, sluit onder meer die volgende in: outeur(s) en datum; steekproef; metings en responskoers (indien gerapporteer); veranderlikes ondersoek (volgens die meetinstrumente) en die verskillende klere-aankooporiëntasies soos gerapporteer deur die navorsers.

Darden (1980:43) se Patronage Model of Consumer Behavior is as die teoretiese vertrekpunt vir die ontleding van die literatuur geneem. Daar is gevind dat veranderlikes wat in samehang met klere-aankooporiëntasies ondersoek is, primêr onder persoonlike eienskappe ressorteer. Navorsers het ook inligtingsbronne as ' $n$ veranderlike by hul ondersoeke ingesluit, sowel as produkeienskappe, winkeleienskappe (waarby winkelbeeld ingesluit is), en winkelvoorkeurgedrag. Dit ondersteun Darden (1980) se model, alhoewel die verwantskappe nie noodwendig empiries getoets is nie. Die klere-aankooporiëntasies wat in die navorsing gerapporteer is, is georden om ' $n$ mate van verfyning te bewerkstellig en ' $n$ klassifikasie daar te stel wat in verdere navorsing gebruik en getoets kan word. Nege kategorieë is in die voorgestelde klassifikasie vervat.

Die belangrikste bydrae van hierdie artikel is om ' $n$ oorsig te gee en tendense in navorsing oor klereaankooporiëntasies uit te wys. Veranderlikes wat met klere-aankooporiëntasies verband hou, is geïdentifiseer en kan empiries ondersoek word met Darden (1980) se model as vertrekpunt. Die voorgestelde klassifikasie van klere-aankooporiëntasies bied ' $n$ riglyn vir die opstel van vraelyste met die oog op empiriese verifikasie.

\section{INTRODUCTION}

Shopping orientation is a complex and multidimensional concept. Defining shopping orientation is extremely difficult, due to numerous interrelated variables. Although the concept shopping orientation is described by researchers from various perspectives, certain major variables (or concepts) are repeated in the different descriptions.

Stone (1954) introduced the concept shopping orientation. He referred to shopping lifestyles or shoppers' styles that place emphasis on certain activities in particular. Other researchers added to this definition by pointing out that shopping-specific lifestyles encompass shopping activities, interests, and opinions. The definitions of shopping orientation reflect a view of shopping as a complex personal, economic, social and recreational phenomenon (Darden \& Howell, 1987; Hawkins et al, 1989:641; Kwon et al, 1991; Shim \& Bickle, 1994; Shim \& Kotsiopulos, 1992a; Shim \& Kotsiopulos, 1993; Shim \& Mahoney, 1992).

Shoppers with different shopping orientations reveal different consumer characteristics and differences in market behaviour, including different needs and preferences for information sources, store preferences and store attributes (Gutman \& Mills, 1982; Lumpkin, 1985; Shim \& Kotsiopulos, 1992a \& 1992b). Jarboe and McDaniel (1987) emphasise that consumers' shopping orientations refer to their general approach to acquiring goods and services and to the nonpurchase satisfactions derived from shopping at retail stores and shopping centres. It may be a function of a variety of nonpurchase motives, such as the need for social interaction, diversion from routine activities, the need for sensory stimulation, exercise, and the exertion of social power (Bellenger \& Korgaonkar, 1980; Kwon et al, 1991). Shopping orientation therefore varies with regard to individuals and different products, among individuals over time, and with changing situations.

Concepts (or variables) related to shopping orientation are not necessarily included in the above-mentioned definitions. Some of the authors refer to concepts such as shopping attitudes (Fuller \& Blackwell, 1992), shopping behaviour (Bellenger \& Korgaonkar, 1980), and shopping motives (Stoltman et al, 1991). One of

\section{- Prof EM Visser}

Department of Consumer Science: Food, Clothing, Housing University of Stellenbosch

\section{- Me R du Preez}

Department of Industrial Psychology

University of Stellenbosch 
the major difficulties encountered in the identification of relevant research on shopping orientation is the fact that some researchers use the term shopping orientation in general, while actually referring to other variables such as perceptions of fashion and perceptions of apparel shopping (Summers et al, 1992).

Based on the above, it could be concluded that the concept shopping orientation consists of a personal dimension (e.g. activities, interests, opinions, motives, needs and preferences) and a market behaviour dimension or a general approach to acquiring goods and services. This market behaviour dimension reflects the personal dimension and indicates needs and preferences for, inter alia, information sources, stores per se (patronage behaviour) and store attributes (including store image).

\section{STATEMENT OF THE PROBLEM}

The overall consensus of previous research is that, to maximise consumer satisfaction and retail sales, retailers need to understand consumers' psychographics and shopping orientations (Shim \& Bickle, 1994; Shim \& Kotsiopulos, 1993). This view is in accordance with Lumpkin (1985) who stated that, for the study of shopping orientation to be beneficial to marketers for matching strategies to consumer needs, it is necessary to link the various shopping orientations to marketplace behaviour. It could be postulated that once apparel consumers with different shopping orientations are identified, other consumer characteristics could be studied among the subgroups. Marketing tactics and strategic approaches could be based on the identification and satisfaction of the different needs of these subgroups. On this basis, it is imperative to investigate consumers' shopping orientations.
Since Stone's (1954) seminal research, numerous researchers have investigated shopping orientations from different perspectives. However, limited attempts have been made to systematically examine the commonalties, differences, and relationships among major variables impacting on shopping orientations, also with regard to apparel as a product category. According to Shim and Kotsiopulos (1992a), research findings regarding relationships among factors influencing shopping orientations appear to be inconsistent. This inconsistency could be attributed to the fact that different products and different consumers were being investigated.

The need to investigate shopping orientations of apparel shoppers was emphasised by Shim and Kotsiopulos (1993). Due to the desirability of studying marketplace behaviour with respect to specified product categories, and the importance of apparel as a product category, it was decided to focus this literature review on apparel shopping orientations.

\section{PURPOSE}

Knowledge of apparel shopping orientations will promote and enhance efforts to develop and/or test theories of shopping behaviour and could guide future research. The purpose of this paper is to give an overview of and to analyse what has been learned collectively from research on apparel shopping orientations. A classification of shopping orientations is proposed and concepts (or variables) that seem to have a relationship or to interact with apparel shopping orientation are identified. Based on these findings, recommendations for future research on apparel shopping orientation could be formulated.

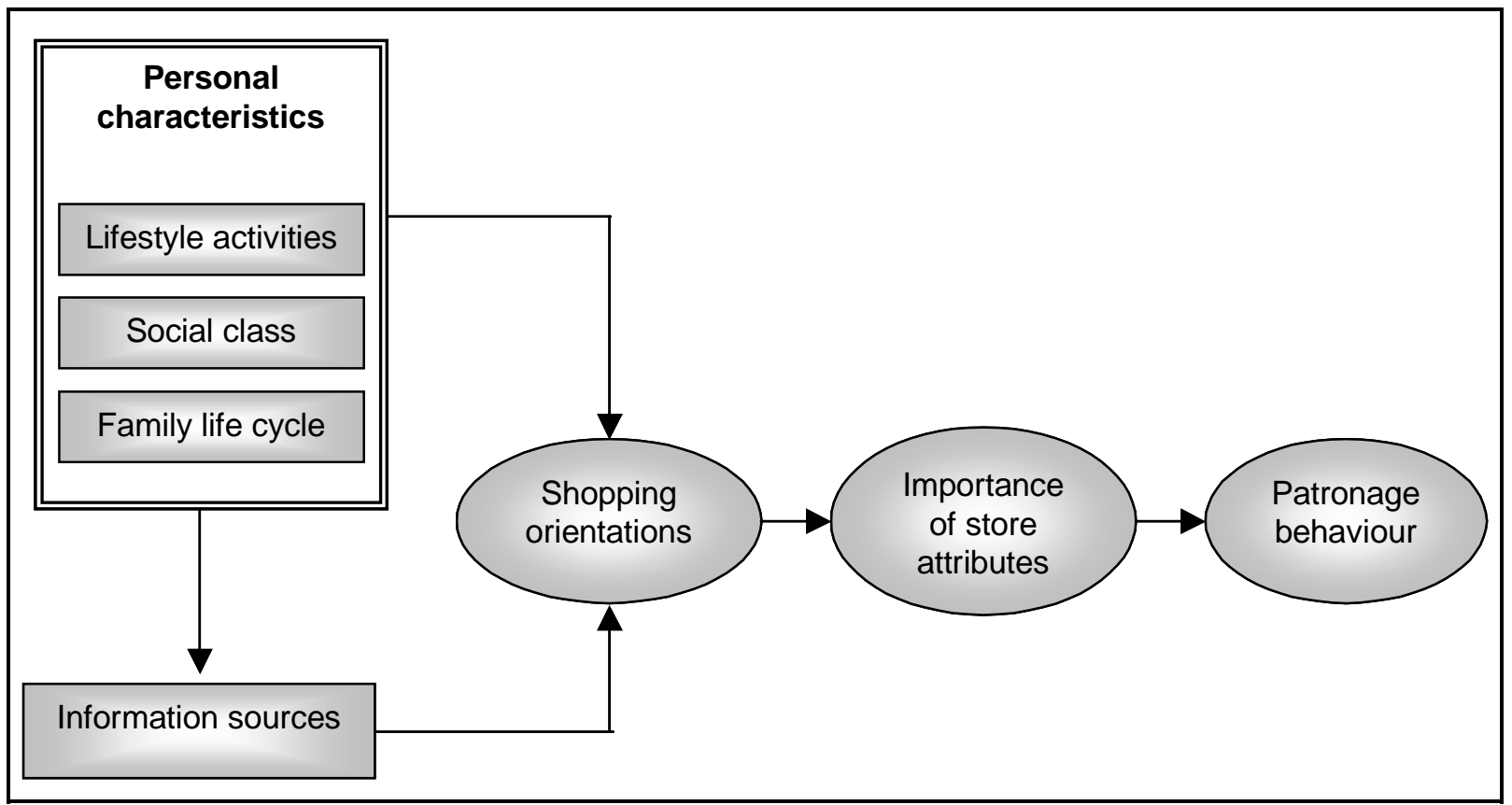

FIGURE 1: DARDEN'S PATRONAGE MODEL OF CONSUMER BEHAVIOUR 


\section{THEORETICAL PERSPECTIVE}

Identifying a theoretical model (or models) that could serve as a point of departure to investigate concepts or variables related to shopping orientation should be done with circumspection. Relevant models do not necessarily include shopping orientation as a separate concept (e.g. the modified Sheth Model of Shopping Preference Determinants (Sheth, 1983:20); Model of Store Choice (Assael, 1995:630); the Engel, Blackwell and Miniard Model of Consumer Decision-process (1995:154); and the Clothing Consumers' Decision Making Model (De Klerk, 1999:127).

The impact of shopping orientations on patronage behaviour has been explicated and documented by several researchers (Shim \& Kotsiopulos, 1992a \& 1992b; Darden \& Howell, 1987; Gutman \& Mills, 1982; Bellenger \& Korgaonkar, 1980; Darden, 1980:43). Darden's (1980:43) Patronage Model of Consumer Behavior (Darden's (1980) Model hereafter) includes shopping orientation as a concept and the model was tested and revised by Shim and Kotsiopulos (1992a \& $1992 b)$ in apparel related research. Consequently it was decided to use this model to guide the analysis of research on apparel shopping orientation reported during the past two decades.

According to Darden's (1980) Model (Figure 1) shopping orientations serve as key constructs in a patronage choice model. The antecedent variables to shopping orientations include personal characteristics (lifestyle activities, social class, and family life cycle), as well as information sources. It is also hypothesised that shopping orientations to a large extent determine the importance of salient store attributes, which, in turn, impact on patronage behaviour (Shim \& Kotsiopulos, 1992a \& 1992b). This reflects the influence of both market-dominated and consumer-dominated variables. Shopping orientations and patronage behaviour could be viewed as variables of market and consumer interaction.

All the above-mentioned models include consumerand market-dominated variables as well as market and consumer interaction variables and refer to, for example, supply-side and demand-side determinants (Sheth, 1983:20), environmental influences, individual differences and marketer-dominated stimuli (Engel et al, 1995:154). The De Klerk (1999) Model points out the interrelationship between characteristics of the apparel consumer and the environment (business and market influences, mass media, stores). According to Moschis (1976), lifestyles and shopping orientations are good predictors of various aspects of shopping behaviour, such as store loyalty and preferences for types of retail outlets. Shopping orientations could also be used to determine choice and application of information by shoppers and to suggest viable promotional strategies. This notion further supports the choice of Darden's (1980) Model as basis for this literature review and analysis of research. This model also corresponds with descriptions and/or definitions of shopping orientations that indicate a personal and market behaviour dimension.

\section{PROCEDURE}

Two procedures were used to search for and to identify relevant research:

- An on-line computer search of publications on shopping orientation.

- A visual search of the major publications in clothing, retailing and shopping behaviour.

The selection of articles was based on the following criteria:

- Empirical research on shopping orientation in general and apparel shopping specifically.

- Publication in a professional journal during the period 1980 to 1999.

The decision to include the most recent two decades was based on the fact that the marketplace is changing drastically and findings might become dated. Shopping orientations of today's generation differ from orientations of past generations due to constant social, cultural, and economic changes in society (Stoltman et al, 1991; Shim \& Kotsiopulos, 1993).

Implementing the above-mentioned criteria posed major obstacles. Many articles were deemed appropriate for inclusion on face value, but studying the details thereof made it clear that concepts related to shopping orientation were investigated (Bloch et al, 1989; Fuller \& Blackwell, 1992; Shim \& Kotsiopulos, 1991; Summers et al, 1992; Thorpe \& Avery, 1983-84). Consequently it was decided to execute a screening process.

The aim of this screening was to prevent inclusion of articles based on concepts related to shopping orientation. Only research articles referring to the concept shopping orientation in the title, objectives, hypotheses and/or measurements were included. Although these articles do not exclusively refer to apparel shopping orientation, they were used for the general description and/or discussion of the concept shopping orientation.

To further focus the investigation necessitated a second screening of the selected articles. From among all the articles that complied with the above-mentioned criteria, only those referring exclusively to apparel shopping orientation were analysed. This decision was based on Shim and Kotsiopulos' (1992a) view that inconsistencies in research findings on shopping orientations could be attributed to the fact that different products were being investigated. Only twelve articles satisfied the above conditions. The following data were recorded:

- Author(s) and date

- Sample

- Measurements and response rate (if reported)

- Variables investigated (according to the measuring instruments)

- Apparel shopping orientations as a basis for market segmentation

- Shopping orientations listed after statistical analysis (original labels) 
The outcome of this analysis will be presented as follows: Firstly, a synopsis of the articles selected for analysis is given (Table 1). Information cited includes the sample size and composition, response rate, the research method and techniques employed to collect data, as well as variables investigated in conjunction with shopping orientation. The variables were listed to accord with the concepts included in Darden's (1980) Model. Secondly, brief comments are given on using apparel shopping orientations as a basis for market segmentation.

Thirdly, a new classification of apparel shopping orientations, based on the information compiled, is proposed (Table 2). The proposed categories are presented in the first column, and the original labels used and the specific researchers in the second and third columns respectively. The primary aim of this categorisation was to refine or reduce the range of often similar shopping orientation labels used by different researchers and to propose a new categorisation that could be used for future research. The empirical identification of these proposed categories is beyond the scope of this research. Lastly, recommendations are given with regard to future research.

\section{OVERVIEW OF RESEARCH}

The different studies included in this overview reflect a variation in sample size (from small $(n=182)$ to very large $(n=6261))$, measurements and response rate (Table 1). Quantitative data were collected, predominantly by means of mail questionnaires. No qualitative research on apparel shopping orientations could be obtained.

The literature was scrutinised to identify the variables which researchers have investigated along with shopping orientation. The primary aim was to reveal relationships among variables and the multidimensional nature of apparel shopping orientations. Based on Darden's (1980) Model, the variables reported by the different researchers were classified under consumer characteristics, store attributes (including product attributes and store image, by implication), information sources (including media search and sources) and retail patronage. It should be taken into account that the researchers listed in Table 1 did not necessarily investigate statistical relationships between these variables and shopping orientations. Certain important tendencies emerged from the analysis and will be highlighted in the following paragraphs.

Two studies were not included in Table 1. Research by Stoltman et al (1991) was not tabulated due to the primary aim of the study being mall choice and the related shopping orientations, such as frequency of shopping, browsing and time consciousness. The results revealed that mall choice was significantly related to these shopping orientations. Kwon et al (1991) investigated shopping orientation and perceived risks involved in purchasing apparel from catalogues. It was found that shopping orientation of catalogue and non-catalogue shoppers did not differ.

\section{Personal characteristics as variables}

Almost all the researchers included personal characteristics in their studies, including variables such as lifestyles (psychographic characteristics) and demographic characteristics, e.g. social class, family life cycle, income, gender, marital status, occupation, education, income, and type of residence. With regard to demographics, it is interesting to note that, although men were not excluded, the investigations were focused mainly on women. The fact that women are perceived as the predominant and "traditional" purchasing agents of apparel for themselves and family members (Fuller \& Blackwell, 1992) could explain this. The research by Shim and Chen (1996) examined acculturation characteristics as predictors of apparel shopping orientations. They viewed shopping orientations as an outcome of the socialisation process in a new cultural setting.

Visser et al (1996) included clothing involvement in their research and reported differences among three cluster groups with regard to their clothing involvement. Fashion orientation was reported by three researchers. Seven apparel-fashion lifestyle segments, i.e. Leaders, Followers, Independents, Neutrals, Uninvolveds, Negatives and Rejectors, were identified by Gutman and Mills (1982). The patterns of scores on shopping orientation revealed that those on the high fashion involvement side of the spectrum (Leaders, Independents, Followers) enjoyed shopping. The Neutrals, as the name implies, were neutral toward shopping. On the low fashion involvement side (Uninvolveds, Negatives, Rejectors), reported shopping enjoyment was low. The Negatives and Rejectors scored high on cost consciousness. The hypothesis that shopping orientation would serve as a predictor of fashion opinion leadership among mature consumers was rejected by Huddleston et al (1993).

The fact that so many researchers included personal characteristics in their research design supported the inclusion of this concept in Darden's (1980) Model. The importance of a personal dimension in shopping orientation is also confirmed. However, personal characteristics (or a personal dimension in shopping orientations) should be qualified by a more explicit delineation of all the components incorporated in this concept or variable. Researchers should aim at the identification of statistically significant relationships, for example, between lifestyles and specific shopping orientations.

\section{Information sources}

Information sources, as a concept in Darden's (1980) Model, seem to be related to both personal characteristics and shopping orientations. Consumers differ with regard to their information search patterns, the media they use, and stage in the decision-making process at which they use specific media and/or information sources. Five out of the twelve studies in this 


\begin{tabular}{|c|c|c|c|c|c|c|}
\hline \multirow[b]{2}{*}{ Author(s) \& date } & \multicolumn{2}{|c|}{ METHODOLOGY } & \multicolumn{4}{|c|}{ VARIABLES } \\
\hline & Sample & $\begin{array}{l}\text { Measurements and response rate (if } \\
\text { reported) }\end{array}$ & 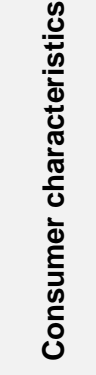 & 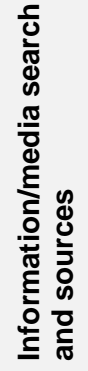 & 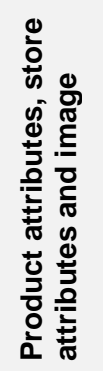 & 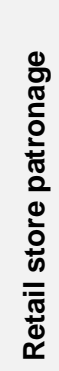 \\
\hline Gutman \& Mills (1982) & 6261 females & Questionnaire - Mail survey $(30.5 \%)$ & $\checkmark *$ & & & $\checkmark$ \\
\hline Huddleston, Ford \& Bickle (1993) & $\begin{array}{l}711 \text { males and females } \\
\text { (readers of } 50 \text { Plus Magazine) }\end{array}$ & Questionnaire - Mail survey (35\%) & $\checkmark \star$ & & & \\
\hline Lumpkin \& Greenberg (1982) & $\begin{array}{l}1741 \text { females } \\
1113 \text { males } \\
\end{array}$ & Questionnaire - Mail survey (65\%) & $\checkmark$ & $\checkmark$ & $\checkmark$ & $\checkmark$ \\
\hline Lumpkin (1985) & 373 mature consumers & Questionnaire - Mail survey (65\%) & $\checkmark *$ & $\checkmark$ & $\checkmark$ & $\checkmark$ \\
\hline Lumpkin, Allen \& Greenberg (1981) & 2676 respondents & Questionnaire - Mail survey (61\%) & $\checkmark$ & $\checkmark$ & $\checkmark$ & $\checkmark$ \\
\hline Shim \& Bickle (1994) & 610 females aged 18 and older & Questionnaire - Mail survey (62\%) & $\checkmark$ & & & $\checkmark$ \\
\hline Shim \& Chen (1996) & $\begin{array}{l}182 \text { male }(55 \%) \text { and female } \\
(45 \%) \text { students }\end{array}$ & Questionnaire - Mail survey $(50.8 \%)$ & $\checkmark$ & & & \\
\hline Shim \& Kotsiopulos (1992 a \& b) & 482 females aged 18 and older & Questionnaire - Mail survey (37\%) & $\checkmark$ & $\checkmark$ & $\checkmark$ & $\checkmark$ \\
\hline Shim \& Kotsiopulos (1993) & 482 females aged 18 and older & Questionnaire - Mail survey (37\%) & $\checkmark$ & $\checkmark$ & $\checkmark$ & $\checkmark$ \\
\hline Visser, Du Preez \& Du Toit (1996) & 212 females aged 55 and older & Questionnaire - Drop off/recollect (58\%) & $\checkmark$ & & $\checkmark$ & \\
\hline
\end{tabular}


review included information sources as a variable in their investigation. No specific relationships were reported by these researchers to confirm the concept figuration proposed by Darden's (1980) Model.

\section{Store attributes and patronage behaviour}

The researchers listed in Table 1 included product attributes and store attributes (six studies), and patronage behaviour (seven studies) in their investigations. This could serve as an indication of the relevancy of these concepts (or variables) when shopping orientation is investigated. It also supports Darden's (1980) Model and the usefulness of this model as point of departure for investigating apparel shopping orientations.

According to Gutman and Mills (1982) and Lumpkin (1985), as well as Shim and Kotsiopulos (1992a \& 1992b), shoppers with different shopping orientations reveal different consumer characteristics and market behaviour that involve different needs and preferences for information sources, store preferences and store attributes. Shim and Kotsiopulos (1992a) found that shopping orientations could be used to predict consumer behaviour. According to the results of their investigation, shopping orientation, store attributes, information sources, and personal characteristics revealed the predictability of patronage behaviour with regard to apparel, but shopping orientation and store attributes were deemed more important. These two researchers revised Darden's (1980) Model and found a direct relationship between shopping orientations and patronage behaviour. Shopping frequency and multipurpose shopping contributed to patronage behaviour, with special reference to mall choice, in a study conducted by Stoltman et al (1991).

Theoretical models on apparel consumer behaviour (e.g. those mentioned above) include both consumerand market-dominated variables, as well as the interaction between consumers and the market. Further evidence of this is found in Sproles' Model of the Fashion Adoption Process which depicts the impact of the adopter's psycho-social motivations (cognitive orientations toward dress, psychological identity, social influences) and influences from the adopter's environment (marketing system, sociocultural change, lifestyles) on consumers' decision-making process (Sproles, 1979:197). On the basis of the above, it seems appropriate to recommend that researchers use Darden's (1980) Model, or even the adaptation by Shim and Kotsiopulos (1992a \& 1992b), when planning research on apparel shopping orientations.

\section{APPAREL SHOPPING ORIENTATION AS A BASIS FOR MARKET SEGMENTATION}

Shopping orientation is regarded as a viable basis for segmentation of apparel shoppers (Lumpkin, 1985). It is often used as a variable in profiling subsegments of shoppers (Shiffman \& Kanuk, 2000:34; Lumpkin, 1985; Lumpkin et al, 1981; Lumpkin \& Greenberg, 1982; Shim \& Bickle, 1994; Visser et al, 1996).
Only three out of the twelve studies included in this review reported consumer profiles that were based on apparel shopping orientations. Lumpkin (1985) distinguished among elderly Uninvolved/Apathetic Shoppers $(24 \%)$, Economic Shoppers (42\%), and Active Shoppers (35\%). The shopping orientation profiles of the cluster groups give information on fashion orientation and activities, as well as financial and shoppingspecific aspects.

Shim and Kotsiopulos (1993) described Highly Involved Shoppers (46\%), Apathetic Shoppers (34\%) and Convenience-oriented Catalogue Shoppers $(20 \%)$. The profiles of apparel shopping orientation clusters give extensive information on patronage behaviour, information usage, demographics, lifestyle and store attributes.

It is surmised from the above-mentioned research that apparel shoppers could be placed on a continuum with apathetic or uninvolved consumers on the one end, and active or highly involved consumers on the other end. The economic and/or convenienceoriented consumers could be concerned with other variables, such as finance and convenience.

To distinguish between heavy and light users of a product, shopping orientation has been used to "vividly contrast" heavy and light users of wearing apparel. Patronage behaviour of heavy and light users also differs (Lumpkin et al, 1981). Shim and Bickle (1994) identified three subsegments of female apparel consumers based on the descriptive benefits sought from apparel products. Shopping orientation differed across the three benefit segments.

Shim and Chen (1996) identified two groups (clusters) of Chinese students, i.e. the Minimalist-Less Acculturated Shoppers (39\%) and the Actively Involved-More Acculturated Shoppers (61\%). The profiles of these two cluster groups based on shopping orientations describe differences in acculturation and demographic characteristics. The fact that people and consumer goods routinely cross international borders highlights the need for research on the relationship between apparel shopping orientation and acculturation. Globalisation and societies characterised by cultural diversity are key factors in planning the marketing mix. Researchers are urged to investigate similarities and differences among apparel shopping orientations of consumers relating to different cultural groups.

It can therefore be concluded that shopping orientation can successfully be used as a variable of market segmentation. The classification of shopping orientations can assist in this regard.

\section{CLASSIFICATION OF SHOPPING ORIENTATIONS}

According to Westbrook and Black (1985), studies on consumer shopping orientations typically seek to identify shopper types to which retailers may direct 
differentiated marketing efforts. In addition, these investigations contribute to an understanding of the taxonomic structure of the consumer population. The first taxonomy of shoppers was offered by Stone (1954), who differentiated among four fairly distinct shopper types on the basis of their shopping orientation, i.e. Economic, Personalising, Ethical and Apathetic Consumers.

Mouton and Marais (1991:137) define a typology as a "... conceptual framework in which phenomena are classified in terms of characteristics they have in common with other phenomena." Classification is one of the more basic functions of conceptual frameworks. In this literature review, an attempt was made to classify those shopping orientations that have been identified by researchers. This is the first step in a process that would ultimately culminate in the systematic collection of data.

The underlying factorial structure of shopping orientation could be postulated from the literature review, by making use of synthesis and logical organisation of existing knowledge. Factor analysis was reported in a number of studies, resulting in the classification of shopping orientations into a factorial structure, with each factor being labelled according to the items loading on that specific factor. In some cases researchers only listed shopping orientations included in their studies, without performing (or reporting) any form of factor analysis. The original labels used by the authors were grouped on the basis of similarity of meaning, to develop a newly proposed categorisation or classification that could be used by researchers.

Table 2 gives the newly proposed categories for the classification of shopping orientations (first column), as well as the original labels of shopping orientations reported (second column) by the respective researchers (third column). The proposed shopping orientation categories are as follows: Activities and Interests Orientation, Brand Conscious Orientation, Confidence versus Confusion Orientation, Enjoyment Orientation, Fashion Orientation, Finance and Credit Orientation, Opinion Leadership Orientation, Patronage Orientation, Shopping and Time Convenience Orientation.

Stoltman et al (1991) listed research-specific shopping orientations that do no fit into the proposed classification. Research findings by Lumpkin et al (1981) were also omitted, due to the integration of lifestyle and shopping orientation. Shopping confusion and "Chinese" consumer ethnocentrism are two shopping orientations identified in Shim and Chen's (1996) study on Chinese students and spouses residing in the United States. Although these two shopping orientations might be research group (respondent)specific, both were deemed important for further investigation, especially because of the fact that societies are increasingly characterised by cultural diversity and dynamism.

Although it is difficult to identify a definite factorial pattern from all the research findings, it seems feasible to categorise shopping orientations into the newly proposed broad categories according to similarities and differences in shopping orientations. This classification synthesises all shopping orientations identified and labelled by researchers into more manageable categories to aid future research, for example when compiling questionnaires and interview schedules. Empirical verification of this proposed classification is not within the scope of this study.

The notion that shopping orientations have both a personal and a market behaviour dimension is confirmed when the different proposed categories are evaluated in Table 2. The personal dimension, however, seems to dominate. This could be explained by the fact that the researchers concentrated mainly on personal (consumer) characteristics and to a lesser extent on market-related behaviour, as is depicted in Table 1. In future, researchers should attempt to link personal characteristics to market-related behaviour. This could reveal untapped apparel shopping orientations.

\section{CONCLUDING REMARKS}

Although apparel shopping orientation has been investigated frequently since Stone's (1954) seminal research, there is little consensus with regard to the underlying structure or dimensionality of apparel shopping orientation. It seems as if the different researchers adapted the measurement of the construct to the nature of the study. The multidimensional nature of apparel shopping orientation complicates investigations. In order to synthesise the cumulative knowledge with regard to apparel shopping orientation and to postulate the possible factorial structure thereof, a thorough literature study was deemed appropriate to establish the cornerstone for further research. The notion that shopping orientations have a personal and a market behaviour dimension was confirmed through the analysis of the research. This could serve as a point of departure for identifying variables to test for relationships.

Understanding shopping orientation of apparel consumers and the implications thereof presents a challenge to researchers in this field of study. They should strive to improve on and to validate generalisations. Many "observations" have been made with regard to apparel shopping orientations, but the nature of the investigations has been relatively unrelated. This issue should be addressed by attempting to theoretically synthesise cumulative knowledge regarding shopping orientations - the main purpose of this literature review.

Researchers could utilise Darden's (1980) Model as a theoretical framework. The concepts in this model seem to be relevant to the investigation of variables impacting on shopping orientation and/or to testing relationships. However, the concept personal characteristics should be elaborated to include more than the three components (lifestyle activities, social class,

Apparel shopping orientation: Two decades of research 
TABLE 2: $\quad$ CLASSIFICATION OF SHOPPING ORIENTATIONS

\begin{tabular}{|c|c|c|}
\hline Proposed category & Original labels & Researchers \\
\hline \multirow{9}{*}{$\begin{array}{l}\text { Activities and interest ori- } \\
\text { entation }\end{array}$} & Personalising shopper & Lumpkin (1985); Lumpkin \& Greenberg (1982) \\
\hline & Interaction with salespeople & Shim \& Chen (1996) \\
\hline & Socially active & Lumpkin (1985) \\
\hline & Shopping interest & Shim \& Chen (1996) \\
\hline & Sports enthusiast & Lumpkin (1985) \\
\hline & Art enthusiast & Lumpkin (1985) \\
\hline & Clothing interest & Lumpkin (1985) \\
\hline & Appearance manager & Shim \& Kotsiopulos (1992 a\&b); Kotsiopulos (1993) \\
\hline & Shopping sex role & Shim \& Chen (1996) \\
\hline \multirow{3}{*}{$\begin{array}{l}\text { Brand-conscious orienta- } \\
\text { tion }\end{array}$} & Brand-conscious & Shim \& Kotsiopulos (1992 a\&b) \\
\hline & Brand-conscious/loyal & Shim \& Kotsiopulos (1993) \\
\hline & $\begin{array}{l}\text { Apathetic toward "Made-in- } \\
\text { USA" }\end{array}$ & $\begin{array}{l}\text { Shim \& Kotsiopulos (1992 a\&b); Shim \& Kotsiopulos } \\
\text { (1993) }\end{array}$ \\
\hline \multirow[t]{5}{*}{$\begin{array}{l}\text { Confidence vs confusion } \\
\text { orientation }\end{array}$} & Confident shopper & $\begin{array}{l}\text { Shim \& Kotsiopolus (1992 a\&b); Shim \& Kotsiopolus } \\
\text { (1993) }\end{array}$ \\
\hline & Shopping self-confidence & Lumpkin (1985); Lumpkin \& Greenberg (1982) \\
\hline & Confident/efficient & Shim \& Bickle (1994) \\
\hline & Shopping alone & Shim \& Chen (1996) \\
\hline & Shopping confusion & Shim \& Chen (1996) \\
\hline \multirow[t]{2}{*}{ Enjoyment orientation } & Shopping enjoyment & $\begin{array}{l}\text { Lumpkin (1985); Lumpkin \& Greenberg (1982); Gut- } \\
\text { man \& Mills (1982); Shim \& Bickle (1994) }\end{array}$ \\
\hline & Shopping propensity & Lumpkin (1985); Lumpkin \& Greenberg (1982) \\
\hline \multirow[t]{5}{*}{ Fashion orientation } & Fashion-oriented shopper & Shim \& Bickle (1994) \\
\hline & Fashion-consciousness & $\begin{array}{l}\text { Shim \& Kotsiopulos (1992 a\&b); Shim \& Kotsiopolus } \\
\text { (1993) }\end{array}$ \\
\hline & Traditionalism & Gutman \& Mills (1982) \\
\hline & Following & Gutman \& Mills (1982) \\
\hline & Conformity & Lumpkin (1985) \\
\hline \multirow[t]{9}{*}{$\begin{array}{l}\text { Finance and credit orien- } \\
\text { tation }\end{array}$} & Credit user & $\begin{array}{l}\text { Lumpkin (1985); Lumpkin \& Greenberg (1982); Shim } \\
\text { \& Bickle (1994) }\end{array}$ \\
\hline & Credit-oriented & Shim \& Kotsiopulos (1993) \\
\hline & Cash-oriented & Shim \& Chen (1996) \\
\hline & Economic shopper & Shim \& Kotsiopulos (1992 a\&b) \\
\hline & Economic/price-conscious & Shim \& Kotsiopulos (1993) \\
\hline & Advertising special shopper & Lumpkin (1985); Lumpkin \& Greenberg (1982) \\
\hline & Cost-consciousness & Gutman \& Mills (1982) \\
\hline & Financial optimism & Lumpkin (1985) \\
\hline & Inflation-conscious & Lumpkin (1985) \\
\hline
\end{tabular}


TABLE 2: $\quad$ CLASSIFICATION OF SHOPPING ORIENTATIONS $(. . . /$ continued $)$

\begin{tabular}{|c|c|c|}
\hline Proposed category & Original labels & Researchers \\
\hline \multirow{3}{*}{$\begin{array}{l}\text { Opinion leadership orien- } \\
\text { tation }\end{array}$} & Opinion leader & Lumpkin (1985) \\
\hline & Shopping opinion leader & Lumpkin (1985); Lumpkin \& Greenberg (1982) \\
\hline & Innovator & Lumpkin (1985) \\
\hline \multirow[t]{4}{*}{ Patronage orientation } & Mall shopper & $\begin{array}{l}\text { Shim \& Kotsiopulos (1992 a\&b); Shim \& Kotsiopulos } \\
\text { (1993) }\end{array}$ \\
\hline & Catalogue shopper & $\begin{array}{l}\text { Shim \& Kotsiopulos (1992 a\&b); Shim \& Kotsiopulos } \\
\text { (1993) }\end{array}$ \\
\hline & Local store shopper & $\begin{array}{l}\text { Shim \& Kotsiopulos (1992 a\&b); Shim \& Kotsiopulos } \\
\text { (1993) }\end{array}$ \\
\hline & $\begin{array}{l}\text { Dissatisfaction with local } \\
\text { shopping }\end{array}$ & Shim \& Bickle (1994) \\
\hline \multirow{7}{*}{$\begin{array}{l}\text { Shopping and time con- } \\
\text { venience orientation }\end{array}$} & Energy-conscious & Lumpkin (1885); Lumpkin \& Greenberg (1982) \\
\hline & Practicality & Gutman \& Mills (1982) \\
\hline & Planning & Gutman \& Mills (1982) \\
\hline & Shopping planning & Shim \& Chen (1996) \\
\hline & My time-oriented & Lumpkin (1985); Lumpkin \& Greenberg (1982) \\
\hline & Time manager & Lumpkin (1985) \\
\hline & $\begin{array}{l}\text { Convenience/time- } \\
\text { conscious }\end{array}$ & $\begin{array}{l}\text { Shim \& Kotsiopulos (1992 a\&b); Shim \& Kotsiopulos } \\
\text { (1993) }\end{array}$ \\
\hline
\end{tabular}

family life cycle) proposed by Darden (1980:43).

The postulated categorisation of shopping orientations should be tested empirically through factor analysis in order to delineate and operationalise the construct shopping orientation. The logical postulation of possible shopping orientation categories based on previous research, should not be confused with the empirical identification of these shopping orientations among selected populations.

Typologies will always hold several advantages for both theory and practice. With this literature review and the proposed categorisation as a basis, researchers could design their investigations to verify the existence of the different shopping orientations. Comprehensive theory building, enrichment of the body of knowledge, and an encompassing understanding of consumer behaviour will result from ongoing investigation and the rigour of scientific proof.

Information on South African apparel shoppers is scant and researchers are urged to focus on the multicultural nature of the South African population. American research findings cannot be accepted unconditionally as valid for South African circumstances, but should be tested empirically. Only one of the articles included in this report refers to the influence of culture on shopping orientation. More research in this regard could identify similarities and differences among consumers of different subcultural groups. Globalisation is a reality that introduces new avenues, responsibilities and challenges for researchers in the field of apparel consumer behaviour.

Winakor (1988), as well as Nagasawa et al (1989), stress the importance of a strong theoretical base for research. The numerous observations about apparel shopping orientations that have been reported are not necessarily structured and aimed at testing, expanding and building theory. This review of research on apparel shopping orientations illuminates some of the difficulties researchers could encounter. It also summarises the variables that have been tested for relationships with shopping orientations and/or have been included in investigations. The postulated categorisation could guide empirical identification and measurement of the suggested shopping orientations. The challenge is for clothing researchers to contribute in this regard.

\section{REFERENCES}

ASSAEL, H. 1995. Consumer behavior and marketing action. $5^{\text {th }}$ ed. Cincinnatti, Ohio. South-Western College Publishing.

BELLENGER, DN \& KORGAONKAR, PK. 1980. Profiling the 
recreational shopper. Journal of Retailing 56(3):77-92. BLOCH, PH, RIDGWAY, NM \& SHERRELL, DL. 1989. Extending the concept of shopping: An investigation of browsing activity. Journal of the Academy of Marketing Science $17: 13-21$.

DARDEN, WR. 1980. A patronage model of consumer behavior. In Stampfl, RW \& Hirschman, E (eds). 1980. Competitive structure in retail markets: The department store perspective. Chicago. American Marketing Association.

DARDEN, WR \& HOWELL, RD. 1987. Socialization effects of retail work experience on shopping orientations. Journal of the Academy of Marketing Science 15(3):52-63.

DE KLERK, HM. 1999. 'n Sosiaal-sielkundige en kognitiewe benadering tot die ontwikkeling van 'n kledingverbruikersbesluitnemingsmodel. Journal of Family Ecology and Consumer Sciences 27(2):116-128.

ENGEL, JF, BLACKWELL, RD \& MINIARD, PW. 1995. Consumer Behavior. $8^{\text {th }}$ ed. New York. Dryden Press.

FULLER, BK \& BLACKWELL, SC. 1992. Wardrobe consultant clientele: Identifying and describing three market segments. Clothing and Textiles Research Journal 10(2):11-17. GUTMAN, J \& MILLS, MK. 1982. Fashion life style, selfconcept, shopping orientation, and store patronage: An integrative analysis. Journal of Retailing 58(2):64-86.

HAWKINS, DI, BEST, RJ \& CONEY, KA. 1989. Consumer behavior: Implications for marketing strategy. $4^{\text {th }}$ ed. Boston. Irwin.

HUDDLESTON, P, FORD, I \& BICKLE, MC. 1993. Demographic and lifestyle characteristics as predictors of fashion opinion leadership among mature consumers. Clothing and Textiles Research Journal 11(4):26-31.

JARBOE, GR \& McDANIEL, CD. 1987. A profile of browsers in regional shopping malls. Journal of the Academy of Marketing Science 15(1):46-53.

KWON, Y-H, PAEK, SL \& ARZENI, M. 1991. Catalog vs non-catalog shoppers of apparel: Perceived risks, shopping orientations, demographics, and motivations. Clothing and Textiles Research Journal 10(1):13-19.

LUMPKIN, JR. 1985. Shopping orientation segmentation of the elderly consumer. Journal of Academy of Marketing Science 13(2):271-289.

LUMPKIN, JR, ALLEN, GS \& GREENBERG, BA. 1981. Profiling heavy-users of wearing apparel. Southern Marketing Association Proceedings, pp167-170.

LUMPKIN, JR \& GREENBERG, BA. 1982. Apparelshopping patterns of the elderly consumer. Journal of Retailing 58(4):68-89.

MOSCHIS, GP. 1976. Shopping orientations and consumer uses of information. Journal of Retailing 52(2):61-70, 93.

MOUTON, J \& MARAIS, HC. 1991. Basic concepts in the methodology of social sciences. Pretoria. Human Sciences Research Council.

NAGASAWA, RH, KAISER, SB \& HUTTON, SS. 1989. Theoretical development in clothing and textiles; Are we stuck in the concrete? Clothing and Textiles Research Journal 7(2):23-31.
SCHIFFMAN, LG \& KANUK, LL. 2000. Consumer behavior. $7^{\text {th }}$ ed. New Jersey. Prentice Hall.

SHETH, JN. 1983. An integrative theory of patronage preference and behavior. In DARDEN, WR \& LUSCH, RF. (eds). 1983. Patronage behavior and retail management. New York. North Holland.

SHIM, S \& BICKLE, MC. 1994. Benefit segments of the female apparel market: Psychographics, shopping orientations, and demographics. Clothing and Textiles Research Journal 12(2):1-12.

SHIM, S \& CHEN, YQ. 1996. Acculturation characteristics and apparel shopping orientations; Chinese students and spouses from the People's Republic of China residing in the Southwest. Clothing and Textiles Research Journal 14 (3):204-215.

SHIM, S \& KOTSIOPULOS, A. 1991. Big and tall men as apparel shoppers: Consumer characteristics and shopping behavior. Clothing and Textiles Research Journal 9(2):1624.

SHIM, S \& KOTSIOPULOS, A. 1992a. Patronage behavior of apparel shopping: Part I. Shopping orientations, store attributes, information sources, and personal characteristics. Clothing and Textiles Research Journal 10(2):48-57.

SHIM, S \& KOTSIOPULOS, A. 1992b. Patronage behavior of apparel shopping: Part II. Testing a patronage model of consumer behavior. Clothing and Textiles Research Journal 10(2): 58-64

SHIM, S \& KOTSIOPULOS, A. 1993. A typology of apparel shopping orientation segments among female consumers. Clothing and Textiles Research Journal 12(1):73-85.

SHIM, S \& MAHONEY, MY. 1992. The elderly mail-order catalog user of fashion products: A profile of the heavy purchaser. Journal of Direct Marketing 6(1):49-58.

SPROLES, GB. 1979. Fashion behaviour toward dress. Minnesota. Burgess.

STOLTMAN, JJ, GENTRY, JW \& ANGLIN, KA. 1991. Shopping choices: The case of mall choice. Advances in Consumer Research 18:434-440.

STONE, GP. 1954. City shoppers and urban identification: Observation on the social psychology of city life. American Journal of Sociology 60(1):36-45.

SUMMERS, TA, BELLEAU, BD \& WOZNIAK, PJ. 1992.

Fashion and shopping perceptions, demographics, and store patronage. Clothing and Textiles Research Journal 11 (1):83-91.

THORPE, DI \& AVERY, CE. 1983-84. A demographic and psychographic assessment of a specialty store's customers and non-customers. Clothing and Textiles Research Journal 2:35-41.

VISSER, EM, DU PREEZ, R \& DU TOIT, JB. 1996. The mature female clothing shopper: Profiles and shopping behaviour. Journal of Industrial Psychology 22(2):1-6. WESTBROOK, RA \& BLACK, WC. 1985. A motivationbased shopper typology. Journal of Retailing 61(1):78-103. WINAKOR, G. 1988. Research in fashion merchandising the need for a theoretical base. Clothing and Textiles Research Journal 7(1):31-35. 